\title{
THE COURSE IN ADVANCED MIDWIFERY AND NEONATAL CARE
}

\section{PAPER PRESENTED AT THE SOUTH AFRICAN MULTIDISSIPLINARY MEDICAL CONGRESS JULY 1981}

\author{
E.M. MACLURE \\ Principal \\ Mowbray Maternity Hospital
}

\section{OPSOMMING}

Die vroedvrou speel vandag 'n belangrike onafhanklike rol in gemeenskapsgesondheidsdienste in Suid-Afrika.

Die behoefte aan 'n gevorderde kursus in verloskunde en neonatale sorg het sy oorsprong in die behoeftes wat geskep word deur die groeiende bevolking, die uitbreiding van die wetenskap en tegnologie en die klemverskuiwing in die lewering van gesondheidsdienste.

Die doel van die kursus is om gespesialiseerde vroedvroue op te lei met besondere vaardighede op die gebied van verloskunde en perinatalogie. Vaardigheid in die lewering van'n hoë gehalte pasiëntesorg in enige situasie is noodsaaklik, maar aspekte soos leierskap, die onderrig van pasiënte en studente sowel as navorsing is ook ter sprake.

Die gevorderde kursus word deur die SA Raad op Verpleging bepaal maar die uitbou van die leergang, keuring van studente, administratiewe en opvoedkundige aspekte, probleme en evaluering is die verantwoordelikheid van die afsonderlike opleidingsinstansies. Die bevindinge en metodes van een instansie wat die kursus aanbied, word bespreek.

\section{"In haar, wat die onsterflikheid bewaak, ontkiem die toekoms in die flou getik van lewe} wat voorwêreldlik ontwaak."

"Die Vrou", Elizabeth Eybers

\section{INTRODUCTION}

According to one dictionary the meaning of Advanced is: to be ahead of most others or at a far-on stage of education, thought, emancipation, life, etc. It has been said that teaching is a success only when it enables students to excel their teachers. How many teachers, clinical or academic, can accept this, albeit with a pang? However, by teaching the teachers, a nucleus of confident enthusiasts can be formed who will be, as it were, the RNA and DNA of the midwifery profession, at $a$ far-on stage of education, thought, emancipation, life, etc.

What is the difference between Midwifery and Obstetrics? Formerly the simple answer would have been: if a doctor does it, it is obstetrics; if a midwife does it, it is midwifery. Since the liberalisation of practice and culpability for misconduct by omission of emergency procedures which can reasonably be expected from a registered midwife the independent decisions and actions of midwives have blurred this simplistic view. It would therefore be arbitrary to assert that anything done by an obstetrician is obstetrics, and anything done by a midwife is pure midwifery.

Why neonatal care? When the South African Nursing Council instituted a post-basic specialist course for midwives, the full title became the Advanced Diploma in Midwifery and in Neonatal Nursing Science. With the pendulum of emphasis swinging from intensive care (in sophisticated hospitals) to preventive, promotive and rehabilitative health care (in the community) the pressure to include neonatal intensive care in this course has gradually lessened. In the average maternity service only about $10 \%$ of newborns need some form of nursery care and only approximately $5 \%$ need intensive care. The importance of the midwife at first contact was recognized after the acknowledgement that early diagnosis of ever-present problems, such as failure of fetal wellbeing, is the main factor in reducing infant and maternal (perinatal) morbidity and mortality.

The timely diagnosis of high-risk groups and their referral to appropriate resources thus creates a more favourable and less fraught outlook for the nine out of ten who tended to be left to a do-it-yourself situation. After all, the majority of parents and babies are doing what Plato defined happiness to be: the performance of natural function.

Through supply and distribution of services and education the midwife rendering advanced midwifery (obstetric) and neonatal care is thus at the core of community health. 
THE NEED FOR AN ADVANCED COURSE

The following are some of the reasons why an advanced course in midwifery and neonatal care is needed:

- the demand for an increased quantity of perinatal care by:

- the population growth per se;

- the community in general;

- the medical profession;

- the implementation of the Health Act, 63 of 1977;

- increasing emphasis on preventive and promotive health services;

- the midwives themselves;

- to establish, maintain and improve the standards of midwifery as a profession. The registered midwife in the Republic of South Africa has practised as an independent practitioner where and when no medical practitioner was available;

- the increasing number of women entering the childbearing age;

- to up-date those midwives who qualified under previous regulations and when different techniques were used;

- to validate the expertise and responsibility of the experienced midwife so that she has the qualification for promotion in the service and can receive a salary notch for the registration;

- to broaden the knowledge, skills and attitudes of midwives to encompass the whole reproductive and perinatal concept in order for her to see midwifery in perspective as the continuum of family health care with the inclusion of parentcraft and the pre-school child;

- the development of obstetric units as a screening facility in the community which are staffed by midwives;

- the regionalisation of perinatal health care services.

\section{AIMS OF THE COURSE}

By offering the advanced course in midwifery it is hoped to achieve the following aims:

- to provide midwives with proficiency in contemporary techniques;

- to equip midwives to perform obstetric emergency procedures in the absence of a medical practitioner,

- to compensate, by the advanced training of midwife-instructors, for any omissions incipient in the reduced clinical practica of integrated courses;

- to enable midwives to be competent in the care of the low and high risk neonate;

- to provide an opportunity for systematic continuing education for experienced midwives who wish to specialise in this field;

- to stimulate interest in midwifery and to maintain a high standard in established training schools;

- to enable registered midwives to set the ideal example of skilled experienced midwifery to students;

— to alleviate the acute and perpetual shortage of midwifery tutors by enabling specialist midwives to perceive themselves as efficient and confident enough to be teaching sisters in the true sense;

- to conform to the principle that the Advanced Midwife is a competent partner to the obstetrician and the neonatologist in ensuring the highest standard of patient care under all conditions;

- to provide midwives who can perform their independent functions competently in developing and remote areas;

- to enable midwives to assist in hospital and community research programmes concerning childbearing and family health;

- to provide practising midwives with a perspective on perinatology and child-rearing;

- to develop midwives as parentcraft and family health educators.

\section{REGULATIONS FOR THE COURSE}

In terms of The Nursing Act 50 of 1978 and the South African Nursing Council Regulation No. R1665 of 3 August 1979, there are rules governing the approval of schools, admission to the course, registration, restoration, termination and completion of the course, duration of the course, the curriculum, lectures, clinical instruction and practica, the examination and examination marks, admission and re-admission to the examination, dates of examinations, applications for admission and fees, examination centres and registration of the additional qualification.

The South African Nursing Council Directive of November 1979 for the course supplies a guide on the objectives of the course, the interpre- tation of course content, the minimum number of teaching periods, the components of the prescribed practica, the essential evaluation strategies, qualifications of lecturers, clinical preceptors, discussion leaders and examiners.

\section{QUALIFICATIONS AND SELECTION OF STUDENTS}

According to the South African Nursing Council Regulation R 1665 a candidate for the advanced course in midwifery and neonatal care is required to be registered as a general nurse and midwife.

It appears however, that at least two years of recent post-registration experience is desirable and when selecting students a break from midwifery of more than one to oneand-a-half years is not acceptable. Importance is also attached to the student's motivation for applying, the outcome of pre-course tests, confidential reports, career expectations and enthusiasm.

It is ideal if one of the selectors can assess a prospective student in a precourse working environment, whether in her own post or at the school offering the course.

It should be emphasised that advanced courses are neither remedial or in-service teaching programmes. Neither should the students be used as an auxiliary work force under the auspices of clinical practica. They are, after all on study leave today it is questionable how much anyone studies after a full day on a ward.

CURRICULUM DEVELOP. MENT, IMPLEMENTATION AND CORRELATION OF THEORY AND PRACTICE

The curriculum was developed to fulfil the needs and achieve the aims of the course.

The content was suggested by a group consisting of:

- principal consultants delegated by the Heads of the Departments of Obstetrics and Gynaecology and of the Department of Child Health for their special interest in these disciplines in relation to midwifery and neonatology combined with enthusiasm and the ability to teach nurses and midwives;

- a regional co-ordinating matron of maternity services; 
- a principal matron of a midwifery training school;

- a principal of a midwifery training school.

Many others were consulted and the resulting mass of suggestions was systematised according to the chronological sequence of reproduction, perinatal care and family health.

At some schools the students attend a two-week course in cervical cytology and a two-week course in family planning, both presented by a regional hospital for the Department of Health, Welfare and Pensions.

Theory and practice are as closely correlated as possible by pacing the study days and clinical placements in step, as shown in the sample schedule (Table 1).

\section{THE ROLE OF MEDICAL PRACTITIONERS}

A valuable component is lost unless the medical practitioners with whom students on an advanced course have professional contact are prepared to allow them to participate (even if it is passively) in teaching and learning situations wherever and whenever they occur. In obstetric and neonatal services clinical material is available or it is not - it certainly cannot or may not be created. The whole object is to avoid possible effects, dangers and complications and care is thus successful when all is delightfully uncomplicated. Hence the self-discipline required of midwives is to nurse to their utmost ability healthy women and their offspring as well as those who are at risk.

Apart from their very necessary involvement in the teaching and development of students to their full potential, the ultimate role of medical practitioners is to accept the Advanced Midwife as a worthy partner in providing perinatal care. If the medical profession will acknowledge the midwife as an authority in her field a great deal of self-respect can be restored to a. somewhat beleagured profession. Many medical practitioners tend to make increasing demands on the midwife but few are consistently prepared to give time and effort to her development.

A most heartening experience is when a super-specialist asks to lecture to an advanced class again. Surely mutual respect will maintain an atmosphere in which everyone can do their best for the benefit of those in their professional orbit.

\section{EDUCATIONAL AND}

\section{ADMINISTRATIVE ASPECTS}

Study leave is granted according to set procedures and amongst reasonable professionals a mutually acceptable arrangement can be made regarding the timing, nature and plough-back of study leave, the latter usually backed by an unwritten ladies' agreement. Hence the impor_ $t$ ance attached during selection to the motivation and career expectations of prospective students.

Apart from the students' salaries, it is possible to present the course at any viable midwifery training school associated with a medical faculty and a teaching hospital. The latter are necessary because the wide scope of the course requires lecturers from various specialities and combined clinics for patients with, for example, medically complicated pregnancies. The specialists are usually willing to give formal or informal tutorials without additional remuneration.

With efficient organisation very little additional equipment is required providing that a physical facility suitable for lectures and informal discussions exists. Kitchen facilities for students are a great advantage as transport can be erratic. Classes of mixed cultures and beliefs can prepare their own refreshments without frustration to themselves or their hosthospital.

However, all teaching centres should be granted a generous library budget as books are a tremendous financial drain to students. An arrangement can sometimes be made with the libraries of medical schools for reading privileges, but their facilities ae usually already fully utilised.

The extent of the course, the supervision of students during clinical practica as well as the organisation and documentation for the course require at least one full-time senior tutor. Obstetric and neonatal godfathers who have a specific interest in the course are invaluable, if not essential.

\section{PROBLEMS ENCOUNTERED}

The following are the main problems which have been encountered:

- the heterogenous nursing background of students;

- the inability of students to use independent study methods, especially discriminate professional reading;
- the inclination of students to concentrate on areas of special interest, usually based on previous experience, such as in the intensive care unit or labour ward;

- transport for students;

— interpersonal relationships between students. Although the class should be small enough to manage as a team, two or more beasts of burden harnessed together to perform a common task, interpersonal relationships become strained, especially towards the time of stress when nearing completion of the course;

- in relation to end of the year festivities and university and school holidays for students with family commitments, the examination in January is difficult. The June alternative can be recommended;

- there is sometimes a lack of acceptance by peers in the clinical situation. There are still many people working in teaching/training units who do not accept constant instruction as an integral part of their daily activity.

Many difficulties are rectified before becoming major problems by having course evaluation meetings (feedback meetings). These meetings are held after each section of the course has been completed, which is approximately trimesterly. The meetings are attended by students, persons in charge of areas in which they work, their midwife preceptors and course leaders.

\section{EVALUATION STRATEGIES Reading and Comprehension}

From the third month of the course, students are given selected articles and other reading materials such as booklets to read and present the following week. They are also expected to lead a discussion on the subject. This activity, which stimulates students to read, paraphrase and think, can be compared with a Journal Club.

From the sixth month, the students are expected to select their own material on a relevant or interesting topic. The topic should preferably have a bearing on the current phase of the course such as pregnancy, labour, puerperium, neonatal care or parentcraft, or on general professional practice.

The reading activity is considered to be of importance for student's future updating. Some students acquire the reading habit and others do not. 
TABLE I: SCHEDULE FOR LECTURES AND CLINICAL PRACTICA FOR THE DIPLOMA IN ADVANCED MIDWIFERY AND NEONATAL NURSING SCIENCE

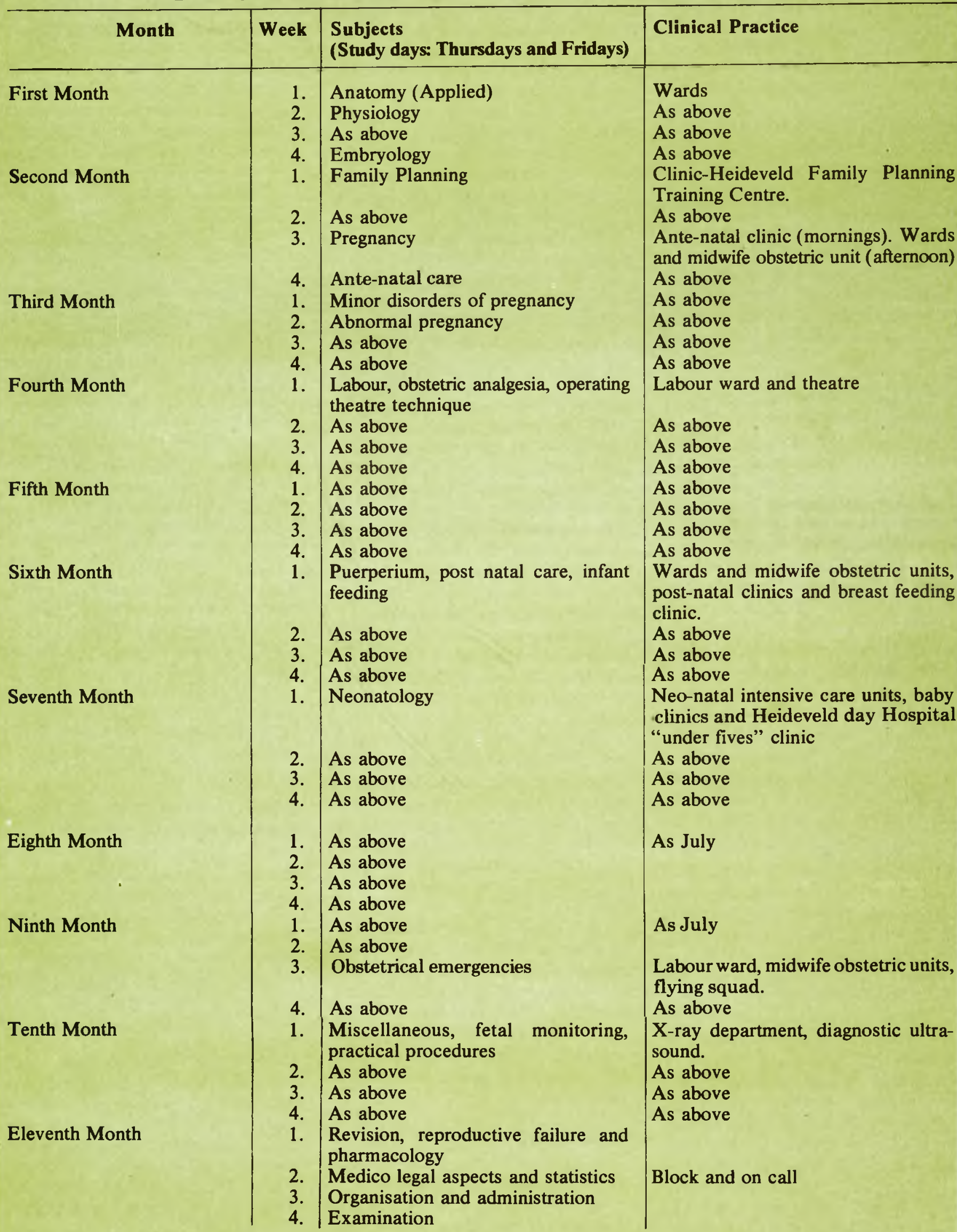

Visits: Monthly perinatal mortality meetings; perinatal pathology meeting, infant post-mortem; Symposium U.C.T. Summer School (e.g. Geneva Conventions) Vista Nova (School for Cerebral Palsied Children); Early learning Centre, Alexandra Institute; Department of Psychiatry - (e.g. counselling for termination of pregnancy); child guidance; Oasis School for Retarded Children. 
TABLE 2: SAMPLE PROCEDURE SHEET

\section{NAME:}

\begin{tabular}{|c|c|c|c|c|}
\hline Department & Date & Supervisor & Procedure & Students Comments \\
\hline Labour Ward & & & $\begin{array}{l}\text { Admission of Patient } \\
\text { Observations and Care } \\
\text { First Stage } \\
\text { A.R.M. } \\
\text { Application and use of monitors } \\
\text { Normal delivery-second and } \\
\text { third stage; immediate after } \\
\text { care } \\
\text { Examination of placenta } \\
\text { Local anaesthetic } \\
\text { Episiotomy and repair } \\
\text { Forceps delivery } \\
\text { Caesarean section: } \\
\text { setting up and taking table } \\
\text { Resuscitation of the newborn }\end{array}$ & \\
\hline Likewise for: & & $\begin{array}{l}\text { linical Instru } \\
\text { inte- and Pos }\end{array}$ & $\begin{array}{l}\text { Out-patient } \mathrm{D} \\
\text { Intensive Care }\end{array}$ & $\begin{array}{l}\text { epartment } \\
\text { e Unit }\end{array}$ \\
\hline
\end{tabular}

\section{Projects}

At the end of each phase of the course the students hand in an assignment. There are four projects, the first on the physiological changes of pregnancy followed by projects on labour, the puerperium and neonatology.

The advanced students also attempt the three South African Nursing Council final examination papers for the Diploma for Registration as a Midwife and the internal hospital final examination. It is very interesting to see the tremendous development of the students between February and October.

In May a major project is allocated to each student. Topics are suggested which are, wherever possible, orientated to the needs or problems of the maternity service or the training school, such as preterm labour; teaching opportunities in the labour ward; antenatal default; nursing care of the neonate at risk. The students inclinations and experience are considered in the allocation of the topic as the intention is to enable them to crystallise their knowledge and past experience. The students are also expected to undertake elementary research for the project.
Procedure sheets and assessment forms

Procedure sheets, part of which is shown in Table 2 as an example, have to be completed during the six to seven weeks before the examinations. Students are allowed to choose suitable assessors among medical practitioners, who are registrars or consultants (full-time and private

practitioners), and nurse-midwives who are principal or senior sisters in charge of specialised departments such as the neonatal intensive unit.

The assessor completes an assessment form (see Table 3) and returns it to the tutor in a sealed envelope. The tutor notates the results on a schedule.

\section{TABLE 3: ASSESSMENT FORM COMPLETED BY ASSESSORS}

Would you please fill in your assessment of

Advanced Midwifery Student

Procedure

and return the form to the lecture room.

Thank you for your assistance.
XX Superb midwife
(above $90 \%$ )
X Excellent
$(80-90 \%)$
S+ More than satisfactory $(70-80 \%)$
S Satifactory
$(60-70 \%)$
S- Less than satisfactory $(50-60 \%)$
D Dangerous
Comment:

Signature: 
As procedures are not always available when required, the search establishes a spirit of co-operation between the classmates and between the students and their assessors. If the tutor does not approve of the assessor, or is not satisfied with the grade achieved by the student, the procedure has to be repeated until proficiency is achieved.

\section{Examinations}

A twenty minute oral examination is conducted by three teams. The panel of examiners for the three teams consists of two obstetricians, two paediatricians, the principal matron of the maternity section of the training school, a matron/inspectress/ principal tutor of maternity services, and an external examiner from a related advanced course such as the Chief Matron, Red Cross War Memorial Childrens' Hospital (paediatric associates).

The oral examination is held after the three written portions have been corrected. Thereafter the examiners meet and discuss the combined results of the examinations and projects to come to final agreement on passes, failures and distinctions (over 75\% throughout).

The results of the oral and written examinations are forwarded to the South African Nursing Council and the successful candidates have the Diploma registered against their names as an additional qualification.

\section{Progress assessments}

Yearly progress assessments of the specialised midwives are obtained on an informal basis.

\section{UTILISATION OF SPECIALISED MIDWIVES}

Whether the specialised midwives are fully utilised or not depends largely on the extent to which the aims of the course have been achieved. The twenty candidates who have been registered by the South African Nursing Council since 1976 are all active in the fertile field of midwifery. Regrettably, one of the past students was boarded after failed treatment of a congenital spinal defect which was only discovered after 30 years of age. Even her talents are not lost as she maintains contact through avid reading and friends in the service and assists in marking scripts and editing notes.

An attempt is made to obtain direct or indirect news of past students. They are functioning as nursemidwife administrators, departmental managers, clinical instructors and, above all, supervisors and managers of patient care.

They have also participated in continuing perinatal education teams arranged by the Cape Provincial Administration in the Eastern and South-Western Cape.

It is hoped that those in possession of this advanced diploma are usable for any midwifery and community health task to which they are called, in their own or any other African country. If there is to be care for all, it will have quality.

I do not need to hope, to endeavour; nor do I need to succeed, to persevere.

William, The Silent

\section{CONCLUSION}

The main distinguishing attributes of a profession are:

- a systematic theory

- authority

- community sanction

- ethical codes

- a culture

By the above criteria the specialised midwives can certainly claim professional status.

With a philosophy of striving for the best in their dual responsibility to society and to their professional successors, quantity care will always have quality as well.

There are still too many empty spaces on the shelves for books, by and for Southern African midwives. Hopefully another achievement of the Advanced Diploma in Midwifery and Neonatal Nursing Science will be the blossoming of the literature which is so essential to any subculture.

Goethe maintained that Man is distinguished by his ability to discriminate and act according to a categorical imperative. Let us hope, then, that the specialised midwife will be distinguished by her refined judgement and timing regarding when to function independently and when to refrain ... then she, by renaissance, will have a quality of life as good as anyone she safely and compassionately brings into this abundant world.

We are the Pilgrims, Master,

We shall go always a little further.

For up on a mountain or dark in a cave

There dwells someone who understands why men are born.

Are we not brave, then,

Who take the Golden Road?

"Hassan”, James Elroy Flecker 